\title{
ПОЛИТИЧЕСКАЯ СИТУАЦИЯ НА УКРАИНЕ В СВЕТЕ ЦЕРКОВНОГО РАСКОЛА
}

Аннотация. В статье проанализирована роль религиозного фактора в той ситуации, которая сложилась в период российско-украинского кризиса. Особое внимание уделено позиииям различных религиозных объединений, прежде всего православных юрисдикций - Русской православной иеркви, Украинской православной иеркви Московского патриархата, УПЦ Киевского патриархата - в общем контексте кризиса между двумя странами и в контексте влияния государственной политики на заявления различных иееквей. По мнению автора, те вызовы, с которыми столкнулись церкви в украинской ситуачии в целом и, главным образом, в ходе военной кампании, ведут к значительным изменениям в их отношениях между собой, с государством, меняют роль ичерквей в своих странах и их позиционирование на постсоветском пространстве. Следствием иерковного раскола становится движение к внутреннему православному конфликту и к расколу самого украинского общества.

Ключевые слова: Украина, межрелигиозный диалог, христианство, православие, протестантизм, религиозное законодательств.

Религиозный фактор исторически был частью политических конфликтов на Украине. Однако если в период присоединения украинских земель к Московской Руси это было противостояние православия и католицизма (или униатства), то в начале XXI в. конфликт приобрёл характер внутриправославного. С 1992 г., когда на Украине возникли параллельные церковные юрисдикции (церкви Киевского патриархата и Московского патриархата), стали естественно возникать различные политические ориентации в православной среде. Как в ходе «оранжевой революции» 2004-2005 гг., так и в ходе евромайдана 2014 г., разделения происходили уже в рамках украинского православия, причём размежевания появились также и внутри УПЦ Московского патриархата. Новая политическая ситуация на Украине после 2014 г. и изменение соотношения сил в пользу Киевского патриархата предопределило обострение конфликта в 2018-2019 гг.

Перетягивание церковных сил не в пользу Московского патриархата происходило постепенно и стало своеобразным прологом к более яркому и стремительному расколу православного мира между Константинопольским и Московским патриархатами. Если ранее при президенте Викторе Януковиче власть в целом была на стороне самой многочисленной и умеренной (в смысле отношения к России) УПЦ МП, то после 2014 г. практически единственной силой, открыто поддерживающей УПЦ МП стал Оппозиционный блок и его лидер депутат Верховной Рады Вадим Новинский.

При участии местных властей и националистов около 40 приходов УПЦ в 2014-2017 гг. были перерегистрированы в рамках Киевского патриархата (УПЦ КП), что в УПЦ расцени-

\footnotetext{
(ㄱ Лункин Роман Николаевич - кандидат философских наук, ведущий научный сотрудник, руководитель Центра по изучению проблем религии и общества ИЕ РАН, заместитель главного редактора журнала «Современная Европа». Aдрес: 125009 , Россия, Москва, Моховая ул., дом 11, стр. 3. $\boldsymbol{E}$ mail: romanlunkin@gmail.com.
}

DOI: http://dx.doi.org/10.15211/vestnikieran62018196202 
вают как «захват храмов» и нарушение религиозной свободы. Кроме того, ряд депутатов Верховной рады ещё в 2017 г. инициировали законопроекты, де-факто направленные против УПЦ. Один из основных законопроектов позволяет признать УПЦ организацией, центр которой находится в стране-агрессоре. В случае его принятия власть получит право контролировать кадровую политику церкви (законопроект №4511 «Об особом статусе религиозных организаций, руководящие центры которых находятся в государстве, признанном Верховной Радой Украины государством-агрессором»). Законопроект №4128 предусматривает внесение поправок, которые позволят религиозным общинам менять юрисдикцию «для удовлетворения своих религиозных потребностей и достойного выражения религиозных чувств» на общем собрании простым большинством. Это позволит сторонникам УПЦ КП регистрировать свои общины в храмах УПЦ.

Верховная Рада на заседании 20 декабря 2018 г. приняла законопроект №5309 «О внесении изменений в закон Украины «О свободе совести и религиозных организаций» по поводу названия религиозных организаций (объединений), которые входят в структуру (являются частью) религиозной организации (объединения), руководящий центр (управления) которой находится за пределами Украины в государстве, которое законом признано осуществившим военную агрессию против Украины и/или временно оккупировало часть территории Украины»". В тексте документа отмечается, что религиозная организация «обязана в своём полном названии, указанном в её уставе (положении), отображать принадлежность к религиозной организации (объединению) за пределами Украины, в которую она входит (частью которой она является), путём обязательного воспроизведения в своём названии полного уставного названия такой религиозной организации (объединения) с возможным добавлением слов «в Украине» и/или обозначения своего места в структуре иностранной религиозной организации»"

17 января 2019 г. Верховная Рада Украины приняла закон об изменении юрисдикции религиозных общин, согласно которому регламентируется порядок изменения подчинённости каждой общины: ${ }^{2} / 3$ голосов членов приходского собрания могут изменить юрисдикцию прихода и храма, здание которого принадлежит приходу. Кроме того, закон ввёл перерегистрацию для всех религиозных организаций до 2020 г., то есть украинские власти поставили перед каждой общиной вопрос о смене юрисдикции.

Политическая целесообразность данных законов была обусловлена созданием под эгидой государства и лично президента П. Порошенко новой церковной структуры на основе Киевского патриархата - Поместной церкви Украины (ПЦУ). В итоге осеннего противоборства, действий Константинополя на Украине и разрыва между Константинопольским патриархатом и РПЦ 15 декабря 2018 г. в Софийском соборе в Киеве прошел объединительный собор, в ходе которого была создана ПЦУ. 6 января 2019 г. в Стамбуле на Фанаре главе ПЦУ митрополиту Епифанию и Петру Порошенко был вручен томос от патриарха Варфоломея и Синода Константинопольского патриархата о создании автокефальной церкви. Таким образом, с точки зрения части украинского истеблишмента и националистических сил произошел желаемый духовный переворот в обществе, и теперь необходимо законодательство и религиозное поле привести в соответствие с произошедшим переворотом.

Справедливости ради надо сказать, что неприятие УПЦ росло также постепенно по мере возникновения ощутимого разрыва с Россией и естественной ассоциации критики российской власти с критикой РПЦ, а значит и подразделения РПЦ в Украине - УПЦ МП.

С патриотических позиций, в том числе критических по отношению к России и к РПЦ, выступает Всеукраинский совет церквей, куда входят и представители УПЦ, часть которых выступает за полное отделение от РПЦ. Однако с наиболее радикальной критикой России и 
УПЦ выступает Киевский патриархат, провозглашающий себя национальной церковью Украины, в отличие от УПЦ, которой будто бы управляет «рука Москвы». Греко-католическая церковь Украины, хотя и поддерживает Киевский патриархат, но вынуждена учитывать умеренную позицию Ватикана по российско-украинскому кризису и его благожелательные отношения с РПЦ после Гаванской встречи в феврале 2016 г.

Обвинения УПЦ в «непатриотичности» строятся, в основном, на предположениях о связях УПЦ с Москвой, и на самом факте наличия в рядах УПЦ верующих и священников, которые симпатизируют России (и таких много на Востоке Украины). В отличие от Киевского патриархата, УПЦ - это церковь, объединяющая людей разных политических взглядов и идентичностей.

Христианских лидеров в России украинские богословы обвиняют в рабской лояльности по отношению к власти - в том, что патриарх Кирилл вместе с президентом Путиным реализуют стратегию «русского мира» на постсоветском пространстве, а протестанты в России идут на компромисс с государством - молчат о происходящем наУкраине или становятся активными патриотами в стиле «Крым наш». Баптистский богослов Михаил Черенков связывает позицию российских лидеров с традицией компромисса и подчиненности власти в эпоху СССР, которой противостоит традиция религиозного диссидентства и плюрализма, существовавшая на Украине ${ }^{1}$. Многие известные пятидесятнические пасторы (пастор церкви «Слово Жизни» в Донецке Леонид Падун и др.) в проповедях почти открыто говорили о необходимости противостоять агрессору в лице России, оправдывая это библейскими сюжетами о том, как «брат воровал у брата».

Вместе с тем, обвинения в адрес РПЦ по иронии судьбы оказались вполне применимы к новой структуре - ПЦУ. Поместная церковь Украины, согласно томосу, является по существу не новой автокефальной церковью, а митрополией Константинопольского патриархата с расширенными правами автономии. На примере Украины патриарх Варфоломей применил новый, не имеющий аналогов, метод предоставления автокефалии национальной церкви, когда церковь оказывается всё равно подчиненной Фанару: не только как главному арбитру, но и контролёру. Экспансия Константинополя воплотилась в переподчинении зарубежных приходов Киевского патриархата себе (и потенциальных приходов ПЦУ за границей) и в создании своего экзархата с центром в Киеве, чтобы всегда быть рядом. И всё это следствие томоса, который задумывался как основание новой независимой украинской церкви (отказ создать патриархат на Украине разочаровал многих). Объединение православных украинцев в одной церкви сейчас ещё более иллюзорно, чем было раньше. Большинство верующих всё равно ходит в храмы УПЦ, а духовенство пока расколоть не удалось. Сторонники ПЦУ считают, что поток после получения томоса и регистрации новой церкви часть УПЦ, в том числе, под давлением властей перейдёт в ПЦУ, но это может только дискредитировать саму идею единой поместной церкви.

Украинские власти проводят операции устрашения в отношении духовенства УПЦ для того, чтобы склонить духовенство к участию в Объединительном соборе и наполнить содержанием указание Порошенко о создании единой церкви. Беседы со священниками в СБУ, призывы чиновников крестить детей только у раскольников, обыски у наместника Киево-Печерской лавры являются явным давлением на Церковь и вмешательством в её жизни, нарушением всех демократических норм. Помимо этого, оказывая влияние на митр. Павла, власти готовятся отдать полностью или частично лавру новой структуре в лице «единой церкви». По-

\footnotetext{
${ }^{1}$ Religion, state, society and identity in transition Ukraine. Rob van der Laarse, Mykhailo N. Cherenkov, Vitaliy V. Proshak, and Tetiana Mykhalchuk, eds. Wolf Legal Publishers. 2015.
} 
ка что силовые структуры оказывают психологическое давление, боясь перейти к активным действиям, так как осознают общественную силу, которой обладает УПЦ.

С другой стороны, появление новой структуры - Поместной церкви Украины - стало объективной реальностью. Для РПЦ это означает усиление раскола в украинском православии, так как бывшие раскольники утвердили свой статус среди части православного мира, который контролирует Константинопольский патриарх. Помимо этого новая церковь получила поддержку со стороны украинской власти и националистов. Без этой помощи со стороны государства ПЦУ так и останется скромной юрисдикцией, она не сможет стать национальной церковью, как это предполагалось. Но возможно этого и не произойдёт. Как это ни парадоксально, националистов не волнует независимость ПЦУ - для них главное - оторвать православие от Москвы, для Порошенко (Тимошенко, Зеленского и Ко) - ПЦУ важна как декорация новой незалежности Украины, а для этого не нужна реальная независимость церкви и её чрезмерное усиление в обществе даже не выгодно.

Реакция других православных церквей на украинский раскол во многом осторожная, церкви неохотно идут на конфликт с Константинополем. Сербская, Антиохийская, Польская церкви высказали свои критические замечания, Греческая церковь отложила решение до своего собора, но вряд ли другие церкви будут предъявлять ультиматум старцу Варфоломею и требовать от него отменить решение. Меры РПЦ будет принимать только, если главы других церквей будут принимать у себя митрополита Епифания и служить с ним, например, одна из близких Фанару церквей Иерусалимский патриархат. Тогда будет заявлено о временном разрыве евхаристического общения и с этой церковью.

Как и в последние 20 лет, православные юрисдикции будут между собой общаться. В 2000-е была даже комиссия по диалогу УПЦ с Киевским патриархатом. Даже после 2014 г. на официальных мероприятиях митр. Онуфрий и Филарет Денисенко приветствовали друг друга. В ситуации, когда две церкви уже противопоставлены друг другу и в политике и личных отношениях между духовенством, они будут интересовать друг друга ещё больше. Переходы из одной церкви в другую - способ решения личных споров, тем более что формально обе церкви теперь относительно каноничны. Реальный диалог между руководством церквей возможен, когда власть перестанет давить как на ПЦУ, так и на УПЦ. Межрелигиозный диалог может быть налажен снова в рамках Всеукраинского совета церквей, где и прежде были и УПЦ и КП.

В ближайшем будущем разрыв с Константинополем, скорее всего, сохранится, никто не пойдёт на уступки - ни патриарх Варфоломей, ни патриарх Кирилл. Да и уступки для каждого из лидеров уже означают потерю Украины, чего ни тот, ни другой допустить не могут. Однако надо сказать, что стратегически для РПЦ и для мирового православия отношения с Константинополем важны, а значит, есть возможность примирения. Условия для мира могут быть самые разные - ПЦУ остаётся как есть под эгидой Фанара, но Константинополь выступает в защиту УПЦ от дискриминации, в ответ РПЦ признаёт только экзархат Константинополя на Украине. Варианты продолжения раскола в будущем не выгодны для УПЦ - всегда неприятно иметь под боком такого раздражителя как ПЦУ. РПЦ, следуя тенденциям российской внешней политики, может пойти на принцип - никаких уступок Фанару, не давать УПЦ статус украинского патриархата (условно, конечно, можно придумать и другую форму, которая порадует украинцев). Но это будет больше работать внутри России, где для политиков также важны декларации и церковные декорации.

Начало 2019 г. ознаменовалось внедрением новой религиозной политики, в ходе которой стала осуществляться дискриминация УПЦ МП. С подписанием закона о смене юрисдик- 
ции общин Пётр Порошенко форсировал ситуацию с развалом УПЦ, и именно поэтому продолжает ту линию, которая была начата им ещё осенью прошлого года по расколу де-факто как мирового, так и украинского православия.

В рамках своей избирательной кампании Порошенко необходимо ускорить все эти процессы, потому что он создал новую структуру, которая пока ничем не наполнена. По сути, это пока искусственная церковь, на основании которой президент должен создать настоящую, наполнив её имуществом, приходами и монастырями. И в этом ему помогут те самые два закона, принятые Радой. То есть, с одной стороны, УПЦ даётся три месяца для того, чтобы самостоятельно изменить название. Если этого не произойдёт, то Украинскую православную церковь лишат регистрации, и это откроет путь для отъёма и захвата её имущества. С другой стороны, этот закон о смене названия церкви подкреплён законом об изменении юрисдикции в каждом приходе. Фактически он облегчает процедуру смены принадлежности того или иного храма в рамках некоего общего собрания, в ходе которого $2 / 3$ должны проголосовать за смену юрисдикции. При этом сложно предположить, кто в таких собраниях будет участвовать. Это открывает путь произволу. По прошествии трёх месяцев, когда УПЦ откажется менять своё название и Министерство культуры лишит её регистрации, закон о смене юрисдикции будет применяться с удвоенной силой.

Власть солидаризировалась со всё более эмоциональными призывами представителей Киевского патриархата о переделе церковного имущества. Ставка патриарха УПЦ КП Филарета (Денисенко) на политическую силу и агрессивную антироссийскую риторику после 2014 г. были для Киевского патриархата (и круга лиц вокруг Филарета) борьбой за самосохранение. Но призыв к власти чуть ли не уничтожить УПЦ и неумение уйти, даже поставив своего преемника, дискредитируют идею независимой церкви Украины.

После создания новой церкви вместо диалога и примирения Филарет стал действовать старыми советскими методами интриг, но в силу возраста это выглядело гротескно, уже отправленный де-факто на покой, то есть на пенсию, лидер приказывает поминать себя на службе, именовать патриархом, уже после создания ПЦУ. В истории Филарет может остаться как создатель независимой, но непризнанной никем и в этом смысле ущербной церкви - Киевского патриархата (имеется в виду структура, которой не удалось добиться томоса от Константинополя, в отличие от «православной церкви Украины»). Получается, как породил Филарет идею независимой церкви, так он её и похоронит в «томос-туре» Порошенко по регионам Украины и в рамках кампании по разделу имущества УПЦ МП.

Следствием церковного раскола становится движение к внутреннему православному конфликту и к расколу самого украинского общества. Хотя украинские СМИ, в частности, портал «Религия в Украине» сообщали лишь о нескольких десятках случаев перехода из УПЦ в ПЦУ, что сложно проверить. В украинском Союзе православных журналистов заявили о захвате представителями ПЦУ Свято-Троицкого храма в селе Ростоки Тернопольской области. В Виннице был захвачен Свято-Преображенский кафедральный собор УПЦ МП, а новому Винницкому митрополиту местные власти отказались передавать документы и регистрировать его в качестве руководителя (в декабре 2018 г. прежнего митрополита Винницкого Симеона (Шостацкого), единственного правящего епископа, который принял участие в Соборе ПЦУ, сменил митр. Варсонофий. Глава УПЦ митр. Онуфрий снял Симеона со своего поста и Синод УПЦ лишил его сана как раскольника, но Симеон отказался подчиняться).

Украинский церковный раскол ярко продемонстрировал, что люди - намного важнее огромного массива собственности. Многотысячные крестные ходы, гражданские активисты в приходах и монастырях в намного большей степени способны спасти Церковь от дальнейше-

Научно-аналитический вестник ИЕ РАН, 2018, №6 
го развала и от оппортунизма и корыстности местного духовенства, чем имущество. Общественная поддержка позиции Церкви вырастает из развития церковной демократии снизу - открытость духовенства, дела милосердия, широкое привлечение добровольцев в социальные и культурные проекты, межконфессиональный диалог. На Украине УПЦ уже ощущает себя гонимой, а политики заявляют о необходимости ликвидации УПЦ. Даже если на новом витке политической истории Украины УПЦ окажется в большем фаворе, чем небольшая Поместная церковь Украины (ПЦУ), то прививка независимости у неё всё равно останется. Отдаление Церкви от власти - это урок, который заставляет церковь трудится в направлении максимальной открытости по отношению к обществу, и, как показывает пример Европы, это почти всегда ведёт к оздоровлению церковной жизни и привлечению активных прихожан.

\section{Список литературы}

Европа XXI века. Новые вызовы и риски: [монография] / под общей редакцией Ал.А. Громыко, В.П. Фёдорова. - М., СПб.: Нестор-История, 2017. - 584 с.

Лункин Р.Н. Европейские церкви и демократические институты: возвращение религии или секуляризация христианства? Вестник Ленинградского государственного университета имени А. С. Пушкина. № 3, 2016. 168-178 с.

Религиозные миссии на общественной арене: российский и зарубежный опыт: [коллективная моногр.] / под ред. А.А. Красикова и Р.Н. Лункина. - М. : ИЕ РАН. С. 59-64.

Партии и движения политической альтернативы в современной Европе. [сб. статей] / [отв. ред. В.Я. Швейцер]. - М. : ИЕ РАН, 2018. С. 36-54.

Лункин Р.Н., Филатов С.Б. Межконфессиональные различия в Европе и новые идеологические противостояния. Современная Европа, №3, 2018. С. 102-114.

\section{References}

Evropa XXI veka. Novye vyzovy i riski: [monografiya] / pod obshchej redakciej Al.A. Gromyko, V.P. Fyodorova. - M., SPb.: Nestor-Istoriya, 2017. - 584 s.

Lunkin R.N. Evropejskie cerkvi i demokraticheskie instituty: vozvrashchenie religii ili sekulyarizaciya hristianstva? Vestnik Leningradskogo gosudarstvennogo universiteta imeni A. S. Pushkina. № 3, 2016. S. 168-178.

Religioznye missii na obshchestvennoj arene: rossijskij i zarubezhnyj opyt : [kollektivnaya monogr.] / pod red. A.A. Krasikova i R.N. Lunkina. - M.: IE RAN. S. 59-64/

Religion, state, society and identity in transition Ukraine. Rob van der Laarse, Mykhailo N. Cherenkov, Vitaliy V. Proshak, and Tetiana Mykhalchuk, eds. Wolf Legal Publishers. 2015.

Partii i dvizheniya politicheskoj al'ternativy v sovremennoj Evrope. [sb. statej] / [otv. red. V.YA. SHvejcer]. - M. : IE RAN, 2018. S. 36-54.

Lunkin R.N., Filatov S.B. Mezhkonfessional'nye razlichiya v Evrope i novye ideologicheskie protivostoyaniya. Sovremennaya Evropa, №3, 2018. S. 102-114. 


\title{
The Political Situation in Ukraine in the Light of the Church Split
}

Authors. Roman Lunkin, Candidate of Sciences (Philosophy), Senior Fellow in the Institute of Europe, Russian Academy of Sciences, the head of the Center for Religious Studies in the Institute of Europe, deputy editor-in-chief of the journal «Contemporary Europe». Address: 11-3, Mokhovaya str., Moscow, Russia, 125009. E-mail: romanlunkin@ gmail.com.

\begin{abstract}
In the article analyzed the religious factor during the Russian-Ukrainian crisis. The special attention payed to the positions of various religious associations, mainly Orthodox jurisdictions and protestant denominations as Russian Orthodox Church, Ukrainian Orthodox Church, Kievan Patriarchate. Their positions analyzed in the context of influence of the state policy on the activity and role of different churches. The author emphasized the challenges that stand before Ukrainian and Russian churches during the military company. The situation changed the mutual relations between not only countries but also churches, changed the role of the churches in their countries and their positioning on the post-soviet space. The consequence of the church split expressed in the move to the internal orthodox conflict and the split inside Ukrainian society in general.
\end{abstract}

Key words: Ukraine, interreligious dialogue, Christianity, Orthodoxy, Protestantism, religious legislation.

DOI: http://dx.doi.org/10.15211/vestnikieran6201815196202 